\title{
Treatment response correlation between primary tumor and axillary lymph nodes after neoadjuvant therapy in breast cancer: a retrospective study based on real-world data
}

\author{
Yu Wang ${ }^{1 \#}$, Longfei $\mathrm{Li}^{2 \#}$, Xiyao Liu ${ }^{3 \#}$, Yihua Wang ${ }^{1}$, Zhenrong Tang ${ }^{1 \wedge}$, Yinan Wu ${ }^{1}$, Yudi Jin ${ }^{1}$, \\ Shengchun $\operatorname{Liu}^{1} \wedge$
}

${ }^{1}$ Department of Endocrine and Breast Surgery, The First Affiliated Hospital of Chongqing Medical University, Chongqing, China; ${ }^{2}$ School of Public Health and Management, Chongqing Medical University, Chongqing, China; ${ }^{3}$ Department of Obstetrics, The First Affiliated Hospital of Chongqing Medical University, Chongqing, China

Contributions: (I) Conception and design: Y Wang, S Liu; (II) Administrative support: Y Wang, L Li, X Liu; (III) Provision of study materials or patients: YH Wang, Z Tang, Y Wu, Y Jin; (IV) Collection and assembly of data: Y Wang, YH Wang, ZR Tang; (V) Data analysis and interpretation: Y Wang, L Li, X Liu; (VI) Manuscript writing: All authors; (VII) Final approval of manuscript: All authors.

\#These authors contributed equally to this work.

Correspondence to: Shengchun Liu, MD, PhD. Department of Endocrine and Breast Surgery, The First Affiliated Hospital of Chongqing Medical University, No. 1 Youyi Road, Yuzhong District, Chongqing 400016, China. Email: liushengchun1968@163.com.

Backgroundk Excellent response of the primary tumor after neoadjuvant therapy may indicate a better axillary status in breast cancer. However, this treatment response correlation has not been investigated in Chinese breast cancer patients.

Mothods: Patients diagnosed with breast cancer and treated with neoadjuvant therapy were included in this retrospective study, conducted at a comprehensive breast cancer institution in China. Clinicopathological factors at baseline were analyzed by univariate and multivariate analyses. Furthermore, association rules analyses were used to investigate the correlation between the pathologic response of the primary tumor and that of the axillary lymph nodes based on such factors.

Results: Multivariate logistic regression analysis showed that breast pathologic response was influenced by tumor size, classification of regional lymph nodes, histological grade, progesterone receptor status, and Ki67 expression. The potential influencing factor for the pathologic response of the axilla was found to be regional lymph node classification. The findings from association rules analyses demonstrated that when a pathologic complete response (pCR) in the breast was achieved among patients with $c \mathrm{~T}_{2} \mathrm{~N}_{0}$ and hormone receptornegative disease, the axilla response in these patients was also highly likely to be pCR (the likelihood for axilla pCR was more than $90 \%$ ). However, $\mathrm{cT}_{3} \mathrm{~N}_{1-2}$ patients hardly achieved $\mathrm{pCR}$ for both the primary tumor and axillary lymph nodes (mean confidence, 0.9637). The clinicopathological factors accounting for the inconsistent response between the breast and the axilla were found to be hormone receptor-positive, human epidermal growth factor receptor 2 (HER2)-negative, and low Ki67 expression.

Conclusions: Our findings suggest a strong correlation between breast pCR and axilla pCR among patients with specific characteristics. These findings provide a basis for the selection of candidates for clinical trials on the omission of axillary surgery.

Keywords: Breast cancer; neoadjuvant therapy; axillary surgery; quality of life (QOL)

Submitted Aug 27, 2020. Accepted for publication Dec 13, 2020.

doi: $10.21037 / g s-20-686$

View this article at: http://dx.doi.org/10.21037/gs-20-686

^ ORCID: Yu Wang, 0000-0001-6350-698X; Zhenrong Tang, 0000-0003-4706-926X; Shengchun Liu: 0000-0002-9933-3643. 


\section{Introduction}

Breast cancer is the most commonly diagnosed malignancy in women and accounts for more female deaths than any other cancer worldwide (1). So far, a wide variety of trials have been designed and performed for treatments of breast cancer. Notably, neoadjuvant therapy (i.e., preoperative therapy) has been acknowledged for its unique and important position in the comprehensive treatment of breast cancer. The goal of neoadjuvant therapy for breast cancer mainly lies in downstaging the tumor, assessing the sensitivity to systemic therapy regimens (such as chemotherapy) beforehand, improving the possibility of breast-conserving surgery, and predicting the long-term risk of recurrence (2-5).

The absence of residual invasive tumor in the breast and lymph nodes after neoadjuvant therapy, which is widely known as pathologic complete response (pCR), often suggests a better prognosis than residual disease $(6,7)$. The rate of pCR varies among the different subtypes of breast cancer, with approximately 30-50\% of human epidermal growth factor receptor 2 (HER2)-positive and triplenegative (defined as hormone receptor-negative and HER2negative) breast cancer (TNBC) patients achieving pCR after standard neoadjuvant therapy, compared with less than $20 \%$ of patients with hormone receptor (HR)-positive breast cancer $(8,9)$. Moreover, the efficacy of neoadjuvant therapy, or the pCR rate, is considered to be related to the characteristics of the patient and tumor before treatment $(10,11)$. For instance, patients with smaller tumors $\left(c T_{1}\right.$ or $c \mathrm{~T}_{2}$ ) usually experience higher rates of pCR. In China, however, data regarding the current situation of neoadjuvant therapy are limited, especially the treatment response and corresponding clinicopathological characteristics for breast cancer. Therefore, neoadjuvant therapy for breast cancer patients in China requires further investigation.

At present, in China, the routine management of axillary lymph nodes after neoadjuvant therapy is axillary lymph nodes dissection (ALND), which unavoidably increases the incidence of complications related to ALND, such as lymphedema, shoulder dysfunction, seroma formation, and loss of sensation in the distribution of the intercostobrachial nerve, which negatively impact quality of life (QOL) (12). Thus, identifying exceptional responders after neoadjuvant therapy, who potentially may not require axillary surgery, meets the requirements of precision medicine. Notably, the findings from an early retrospective study also suggested that the invasive tumor content was more likely to be eradicated from the primary tumor if there was no measurable disease in the axillary lymph nodes (13). On the basis of this observation, it is reasonable to hypothesize that an excellent response of the primary tumor after neoadjuvant therapy, or no residual invasive tumor, may indicate a better axillary status (no or few metastases in the axillary lymph nodes) in patients with breast cancer. Interestingly, two studies from MD Anderson Cancer Center suggest that such a correlation most likely exists, and proposed that it is rational to omit axillary surgery in specific populations ( $\mathrm{cN}_{0} \mathrm{HER} 2-$ positive or TNBC diseases with no residual invasive content in the breast after neoadjuvant chemotherapy) treated with neoadjuvant therapy $(14,15)$. In particular, Barron et al. and Tadros et al. reported the rate of pathologic nodal positivity to be extremely low (less than 2\%) in HER2-positive or TNBC patients with $\mathrm{cN}_{0}$ diseases $(14,15)$. However, these two studies focused on the population registered in the National Cancer Database (NCDB) of the United States, and the exact characteristics of such patients in the Chinese population remain undetermined.

In this report, we used real-world data from a comprehensive breast cancer institution in western China to investigate the associated factors that may play a role in the efficacy of neoadjuvant therapy for the primary tumor and axillary lymph nodes, respectively. Furthermore, the treatment response correlation between the primary tumor and axillary lymph nodes after neoadjuvant therapy was also analyzed with the aim of guiding the screening of different candidates with corresponding specific characteristics.

We present the following article in accordance with the STROBE reporting checklist (available at http://dx.doi. org/10.21037/gs-20-686).

\section{Methods}

\section{Study design and participants}

From January 1, 2012 to December 31, 2018, this retrospective study collected and reviewed data from a comprehensive breast cancer institution in western China, the First Affiliated Hospital of Chongqing Medical University. The institutional ethics committee reviewed and approved this study (No. 2020-59). Due to the retrospective nature of the research and the concealment of patient information, the need for informed consent was waived. The study was performed in accordance with the Declaration of Helsinki (as revised in 2013).

Breast cancer patients who received standard neoadjuvant therapy (e.g., anthracycline- and/or taxane-based neoadjuvant 
chemotherapy, anti-HER2 therapy, neoadjuvant endocrine therapy) followed by breast and axillary surgery were identified. Patients with metastatic disease $\left(M_{1}\right)$ were excluded. All patients were diagnosed by core needle biopsy before the initiation of neoadjuvant treatment at our hospital. The suspected axillary lymph nodes were assessed by core needle biopsy to obtain histological evidence before neoadjuvant therapy, or by clinical physical examination or ultrasonography. The following patient demographic and clinical characteristics at baseline were collected: age, menstrual status, lesion side, clinical TNM (cTNM) staging, pathological reports of biopsy [including histology, immunohistochemical analysis, or fluorescence in situ hybridization (FISH)], treatment regimen, and course of chemotherapy.

\section{Definitions}

A pCR of the breast primary tumor was defined as the absence of residual invasive carcinoma in the excisional breast specimen, while a pCR of the axillary lymph nodes was defined as the absence of measurable or metastatic disease in the excisional specimens of axillary lymph nodes.

\section{Statistical analysis}

Univariate analysis (Pearson's chi-squared test for categorical variables and non-parametric Wilcoxon ranksum test for ordinal variables) was used to determine the correlation between baseline characteristics and treatment response of the primary tumor and axillary lymph nodes, respectively. To estimate the effect of these factors on the response of the primary tumor and axillary lymph nodes, in line with the widely used recommendations (16), variables with a $P$ value lower than 0.25 in the univariate analysis and those with clinical importance were selected as independent variables and analyzed by multivariate logistic regression. All tests were two-sided, and $\mathrm{P}$ values lower than 0.05 were regarded as being statistically significant $(\mathrm{P}<0.05)$.

Association rules analyses were conducted to investigate the association patterns between primary tumor responses and the responses of axillary lymph nodes, as well as to identify the corresponding characteristics of the patients and tumors. Apriori is the most frequently applied machinelearning algorithm for association rules mining (17), which is an effective statistical procedure in which association patterns in data are identified and presented in the form of a series of rules (18). Typically, mined association rules comprise two parts: an antecedent (or left-hand-side, LHS) and a consequent (or right-hand-side, RHS). To describe and represent the interest and significance of a rule, basic metrics (support, confidence, and lift) are utilized. Support is defined as the frequency of one rule occurrence in the total dataset, while confidence is the probability of the RHS in cases of fulfilling the LHS, thus reflecting the reliability of the inference drawn by that rule (LHS $\rightarrow$ RHS). Additionally, as a measure of significance, lift is a factor defined as the realistic probability of co-occurrence of LHS and RHS in a rule divided by the expected probability of LHS and RHS co-occurring, assuming that both of them are independent. Therefore, lift measures the strength of one rule, which can be interpreted as effective association when it is greater than 1. Moreover, the higher the lift, the more significant the rule is. In the current analyses, association rules mining was performed under the condition of minimum support of 0.05 and minimum confidence of 0.75 , according to the recommendations (19).

Univariate analysis and multivariate logistic regression were performed using Statistics Analysis Software (version 9.4, SAS Institute Inc, Cary, NC, USA). Association rules analyses were implemented in the arules $\mathrm{R}$ package of $\mathrm{R}$ software (version 3.5.2).

\section{Results}

A total of 1,312 patients were included in the final analysis. Table 1 summarizes the characteristics of the patients and tumors at baseline. Of the included patients [median age, 49 (IQR 43-56) years], 517 patients were diagnosed during the perimenopausal period, 450 were premenopausal, and 345 were postmenopausal. As far as the lesion side of primary tumor, 695 women had left tumors while 612 patients had right tumors. Most of these patients had $\mathrm{cT}_{2}(70.8 \%)$ or $\mathrm{cN}_{1}(45.8 \%)$ disease. Regarding the pathological reports, patients with invasive ductal histology accounted for the largest proportion (97.7\%), and most of the tumors were classified as grade II (55.8\%). In the immunohistochemical analysis or FISH of the excised specimens, the majority of the patients were estrogen receptor (ER)-positive (60.6\%), progesterone receptor (PR)-negative (53.8\%), and HER2negative (50.1\%), and had high Ki67 expression (72.6\%). After being selected as the candidates for neoadjuvant therapy, most of the included patients were treated with chemotherapy $(97.9 \%)$ and the courses of treatment were mainly less than five cycles (92.5\%).

The types of surgery and treatment response after 
Table 1 Patient demographic and clinical characteristics at baseline

\begin{tabular}{|c|c|}
\hline Characteristic & Total population $(n=1,312), n(\%)$ \\
\hline Age (years) & 49 [43-56] \\
\hline \multicolumn{2}{|l|}{ Menstrual status } \\
\hline Premenopausal & $450(34.3)$ \\
\hline Perimenopausal & $517(39.4)$ \\
\hline Postmenopausal & 345 (26.3) \\
\hline \multicolumn{2}{|l|}{ Lesion side } \\
\hline Left & $695(53.0)$ \\
\hline Right & $612(46.6)$ \\
\hline Bilateral & $1(0.1)$ \\
\hline Unknown & $4(0.3)$ \\
\hline \multicolumn{2}{|l|}{ cTNM staging $^{\dagger}$} \\
\hline \multicolumn{2}{|l|}{ cT } \\
\hline $\mathrm{T} 1$ & $130(9.9)$ \\
\hline T2 & $929(70.8)$ \\
\hline T3 & $247(18.8)$ \\
\hline Unknown & $6(0.5)$ \\
\hline \multicolumn{2}{|l|}{$\mathrm{cN}$} \\
\hline NO & $490(37.3)$ \\
\hline $\mathrm{N} 1$ & $601(45.8)$ \\
\hline N2 & $166(12.7)$ \\
\hline N3 & $54(4.1)$ \\
\hline Unknown & $1(0.1)$ \\
\hline \multicolumn{2}{|l|}{ cM } \\
\hline Mo & $1,312(100.0)$ \\
\hline \multicolumn{2}{|l|}{ Histology (biopsy) } \\
\hline Invasive ductal & $1,282(97.7)$ \\
\hline Invasive lobular & $15(1.1)$ \\
\hline Special types ${ }^{\ddagger}$ & $10(0.8)$ \\
\hline Unknown & $5(0.4)$ \\
\hline \multicolumn{2}{|c|}{ Histological grade (biopsy) } \\
\hline I & $34(2.6)$ \\
\hline II & $731(55.8)$ \\
\hline III & $163(12.3)$ \\
\hline Unknown & $384(29.3)$ \\
\hline
\end{tabular}

Table 1 (continued)
Table 1 (continued)

\begin{tabular}{|c|c|}
\hline Characteristic & Total population $(n=1,312), n(\%)$ \\
\hline \multicolumn{2}{|l|}{ ER status (biopsy) } \\
\hline Positive & $795(60.6)$ \\
\hline Negative & $514(39.2)$ \\
\hline Unknown & $3(0.2)$ \\
\hline \multicolumn{2}{|l|}{ PR status (biopsy) } \\
\hline Positive & $600(45.7)$ \\
\hline Negative & $706(53.8)$ \\
\hline Unknown & $6(0.5)$ \\
\hline \multicolumn{2}{|l|}{ HER2 (biopsy) ${ }^{\S}$} \\
\hline Positive & $447(34.1)$ \\
\hline Negative & $657(50.1)$ \\
\hline Unknown & $208(15.8)$ \\
\hline \multicolumn{2}{|l|}{ Ki67 expression (biopsy) $)^{\pi}$} \\
\hline High & $953(72.6)$ \\
\hline Low & $350(26.7)$ \\
\hline Unknown & $9(0.7)$ \\
\hline \multicolumn{2}{|l|}{ Regimen } \\
\hline Chemotherapy & $1,285(97.9)$ \\
\hline $\begin{array}{l}\text { Anthracycline- and tax- } \\
\text { ane-based }\end{array}$ & $1,278(99.5)$ \\
\hline Anthracycline-based only & $1(0.1)$ \\
\hline Taxane-based only & $6(0.4)$ \\
\hline $\begin{array}{l}\text { Chemotherapy + An- } \\
\text { ti-HER2 }\end{array}$ & $24(1.8)$ \\
\hline Endocrine therapy & $1(0.1)$ \\
\hline Unknown & $2(0.2)$ \\
\hline \multicolumn{2}{|c|}{ Course of chemotherapy (cycles) } \\
\hline $2-4$ & $1,213(92.5)$ \\
\hline $5-8$ & $96(7.3)$ \\
\hline Unknown & $3(0.2)$ \\
\hline
\end{tabular}

Data are shown in median (IQR) or number of patients (\%). ER estrogen receptor; PR, progesterone receptor; HER2, human epidermal growth factor receptor $2 .{ }^{\dagger}$, the clinical staging of disease was documented according to the $8^{\text {th }}$ edition of AJCC (American Joint Committee on Cancer) Cancer Staging Manual (20); ${ }^{\ddagger}$, special types in histology included mucinous carcinoma $(n=6)$, spindle-cell carcinoma $(n=1)$, carcinosarcoma $(n=2)$, and tubular carcinoma $(n=1) ;{ }^{\S}$, the status of HER2 was determined by either immunohistochemical analysis or fluorescence in situ hybridization (FISH); ", Ki67 expression was classified as high when ki67 index was no lower than $14 \%$, else categorized as low. 
Table 2 The types of surgery and treatment response after neoadjuvant therapy

\begin{tabular}{lc}
\hline Variable & $\begin{array}{c}\text { Total population }(\mathrm{n}=1,312), \\
\mathrm{n}(\%)\end{array}$ \\
\hline Surgery & $1,287(98.1)$ \\
Mastectomy & $1,245(96.7)$ \\
Modified radical mastectomy & $24(1.9)$ \\
Radical mastectomy & $18(1.4)$ \\
Skin-sparing mastectomy & $25(1.9)$ \\
Breast conserving surgery & \\
Treatment response & \\
Response of primary tumor ${ }^{\dagger}$ & $153(11.7)$ \\
pCR & $1,145(87.2)$ \\
No pCR & $103(9.0)$ \\
cCR & $618(54.0)$ \\
PR & $395(34.5)$ \\
SD & $29(2.5)$ \\
PD & $14(1.1)$ \\
Unknown & \\
\hline
\end{tabular}

Table 2 (continued)

neoadjuvant therapy are shown in Table 2. Mastectomy (98.1\%) was the most common procedure following neoadjuvant therapy, of which modified radical mastectomy was performed most frequently (96.7\%). Furthermore, responses of the primary tumors and axillary lymph nodes were also presented as shown in Table 2.

\section{Association between clinicopathological factors and the response of primary tumors}

In the univariate analysis as shown in Table 3, cT and $\mathrm{cN}$ classification, histological grade, ER status, PR status, HER2 and Ki67 expression were selected $(\mathrm{P}<0.25)$. These factors and those with known clinical importance (menstrual status, lesion side, course of chemotherapy, and regimen) were then included in the multivariate logistic regression analysis presented in Table 4. The final results showed patients with a larger tumor size $\left[\mathrm{cT}_{2}\right.$ : odds ratio $(\mathrm{OR}) 0.306$; $\mathrm{cT}_{3}$ : OR 0.182; $\left.\mathrm{P}<0.05\right]$, higher classification of regional lymph nodes $\left(\mathrm{cN}_{1}\right.$ : OR 0.341; $\mathrm{cN}_{2-3}$ : OR 0.357; $\left.\mathrm{P}<0.05\right)$, higher histological grade (Grade II: OR 0.184, $\mathrm{P}<0.05$ ),
Table 2 (continued)

\begin{tabular}{lc}
\hline Variable & $\begin{array}{c}\text { Total population }(\mathrm{n}=1,312), \\
\mathrm{n}(\%)\end{array}$ \\
\hline Response of axillary lymph nodes \\
ypN $^{\ddagger}$ & \\
ypN0 & $491(37.4)$ \\
ypN1 & $363(27.7)$ \\
ypN2 & $245(18.7)$ \\
ypN3 & $169(12.9)$ \\
Unknown & $44(3.3)$ \\
Axilla response & \\
pCR & $491(37.4)$ \\
No pCR & $777(59.3)$ \\
Unknown & $44(3.3)$ \\
\hline
\end{tabular}

Data are shown in number of patients (\%). pCR, pathologic complete response; $c C R$, clinical complete response; PR, partial response; SD, stable disease; PD, progressive disease; DCIS, ductal carcinoma in situ. ${ }^{\dagger}$, a pCR of the primary tumor for breast cancer referred to no evidence of residual invasive carcinoma (DCIS allowed) in the excisional breast specimen according to Miller \& Payne classification (21). However, the objective response rate of primary tumor was evaluated on the basis of RECIST 1.1 (the Response Evaluation Criteria in Solid Tumors, version 1.1) principle, as classified as $C C R, P R, S D$ and $P D$ (22); ${ }^{\ddagger}$, the pathologic classification of axillary lymph nodes after neoadjuvant therapy was documented according to the $8^{\text {th }}$ edition of AJCC (American Joint Committee on Cancer) Cancer Staging Manual (20); ${ }^{\S}$, a pCR of the axillary lymph nodes was defined as absence of measurable or metastatic disease in the excisional specimen of axillary lymph nodes, otherwise regarded as no $\mathrm{PCR}$.

and positive $\mathrm{PR}$ status (OR $0.375, \mathrm{P}<0.05)$ were less likely to achieve breast pCR. Conversely, tumors with a high expression of Ki67 had a greater likelihood of breast pCR than those with low Ki67 expression (OR 1.907, $\mathrm{P}<0.05)$.

\section{Association between clinicopathological factors and axilla response}

When analyzed in the univariate analysis (Table 5), clinicopathological factors including menstrual status, lesion side, $\mathrm{cT}$ and $\mathrm{cN}$ classification, histology, histological grade, ER and PR status, and Ki67 expression were identified $(\mathrm{P}<0.25)$. With the use of multivariate logistic regression analysis (Table 6), axilla response was less likely to achieve 
Table 3 Association between clinicopathological factors and the response of primary tumors (univariate analysis)

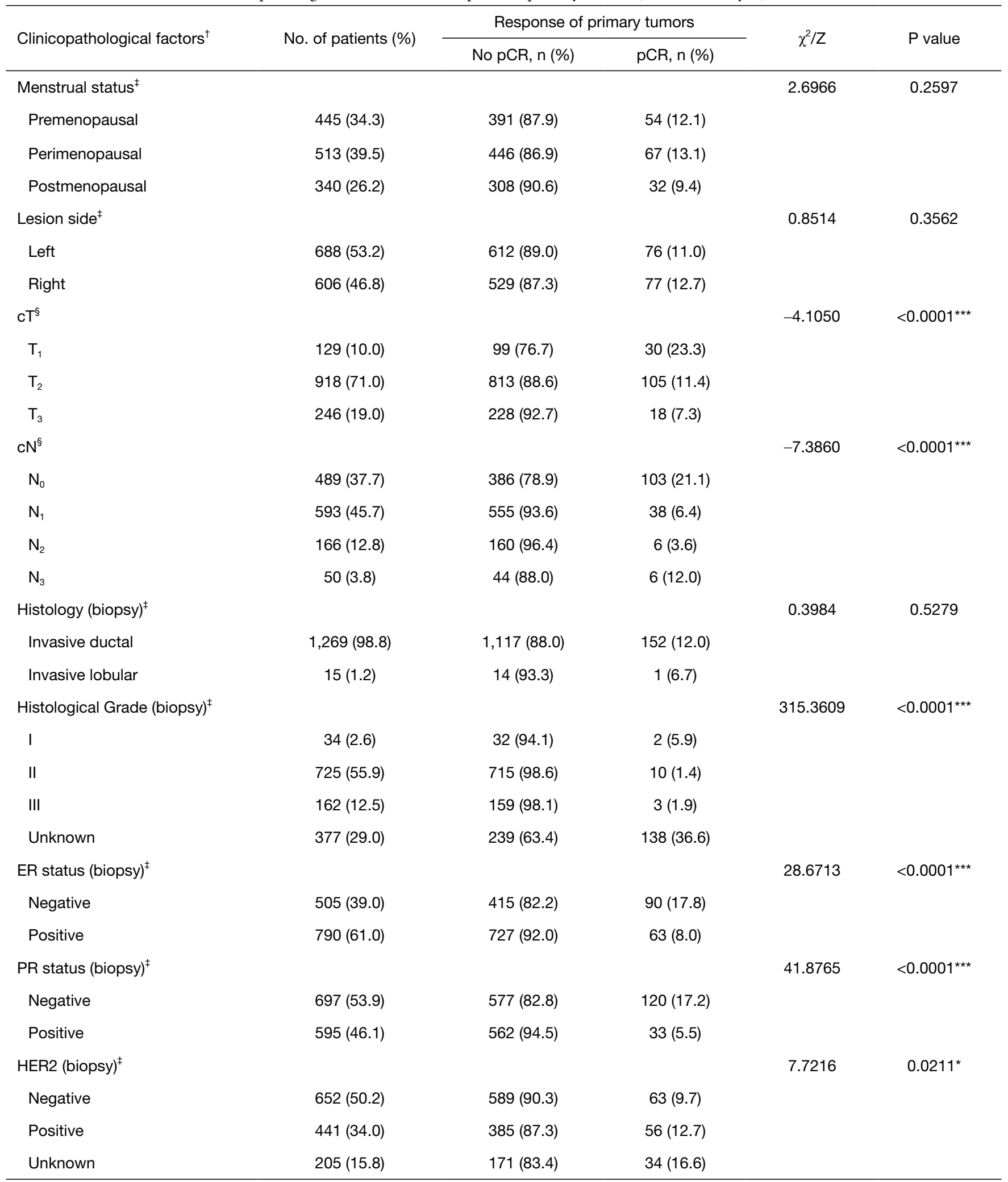

Table 3 (continued) 
Table 3 (continued)

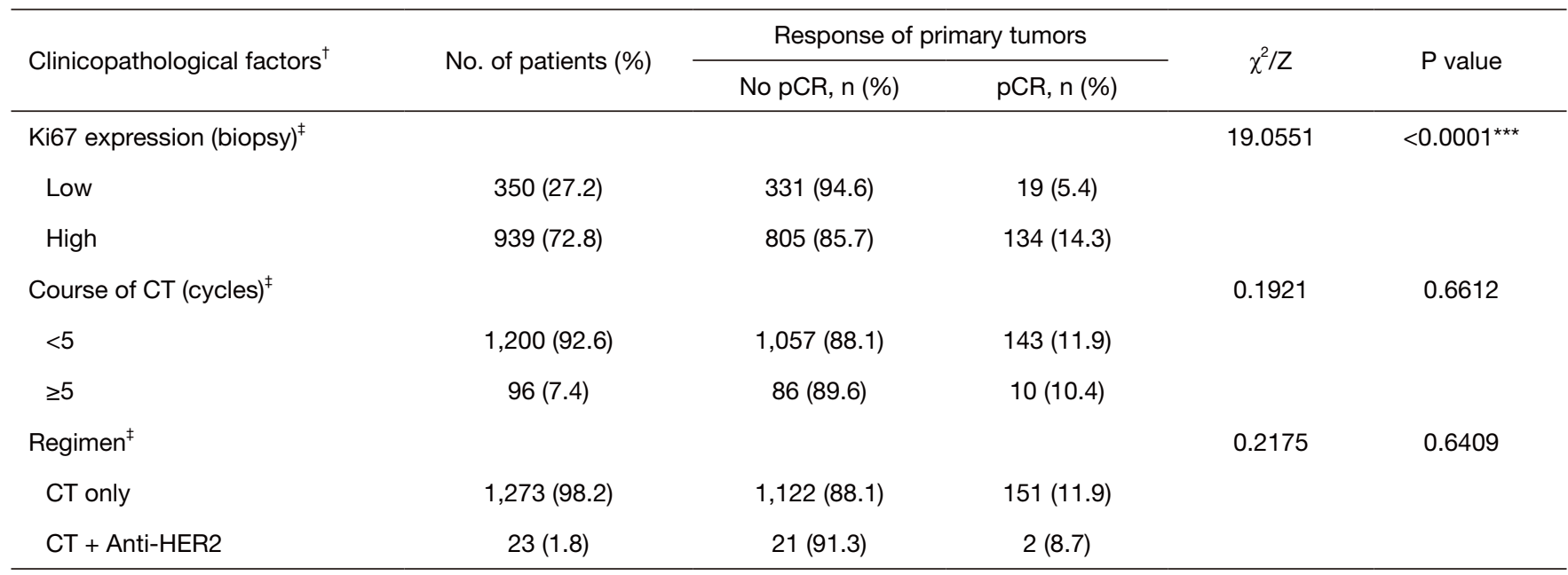

${ }^{\dagger}$, Those clinicopathological factors with fewer than 10 patients were excluded in this analysis; ${ }^{\ddagger}$, Chi-squared test was used; ${ }^{\S}$, Wilcoxon rank-sum test was used; *, $\mathrm{P}<0.05$; ${ }^{\star \star \star}, \mathrm{P}<0.001$. pCR, pathologic complete response; ER, estrogen receptor; PR, progesterone receptor; HER2, human epidermal growth factor receptor 2; CT, chemotherapy.

pCR when the clinical classification of regional lymph nodes was more advanced $\left(\mathrm{cN}_{1}\right.$ : OR $0.008 ; \mathrm{cN}_{2-3}$ : OR 0.006; $\mathrm{P}<0.05)$. However, higher histological grade was associated with higher possibility of axillary pCR (Grade II: OR 3.446, $\mathrm{P}<0.05)$.

\section{Association rules analyses between breast response and axilla response}

Table 7 shows the top 20 association rules between breast pCR and axilla pCR, sorted by confidence and lift. Overall, there was a treatment response correlation between breast pCR and axilla pCR. Specifically, when a breast pCR was achieved in patients with $\mathrm{cT}_{2} \mathrm{~N}_{0}$ and HR-negative (ERnegative and PR-negative) diseases, the probability of axilla pCR was more than 90\% [mean confidence, 0.9351 (95\% CI, 0.9255-0.9447), SE, 0.00478; mean lift, 2.4321(95\% CI, 2.4073-2.4569), SE, 0.01239; Table 7 and Table S1].

As for unfavorable response (no pCR) in both the breast and the axilla, patients diagnosed with $c \mathrm{~T}_{3} \mathrm{~N}_{1-2}$ disease and treated with fewer than five-cycle chemotherapy were highly likely to achieve no pCR for the primary tumor and axillary lymph nodes at the same time [mean confidence, 0.9637 (95\% CI, 0.9516-0.9759), SE, 0.00599; mean lift, 1.3245 (95\% CI, 1.2485-1.4005), SE, 0.03757; Tables S2-S5]. Again, this finding demonstrated the consistency between breast response and axillary response under certain specific conditions.

According to the pooled analysis of the rules in Tables S2,S3,S6,S7, compared with advanced regional lymph node classifications $\left(\mathrm{cN}_{1}\right.$ or $\left.\mathrm{cN}_{2}\right), \mathrm{cN}_{0}$ was shown to be a predictor of axillary pCR [mean confidence, 0.9453 (95\% CI, 0.9317-0.9588), SE, 0.00670; mean lift, 1.9898 (95\% CI, 1.8458-2.1337), SE, 0.07118].

HR-positive (ER-positive and PR-positive) status, HER2-negative status, and low Ki67 expression were highly likely to be the characteristics responsible for inconsistency between the responses of the breast and the axillary lymph nodes [mean confidence, 0.9563 (95\% CI, 0.9460-0.9666), SE, 0.00504; mean lift, 1.5570 (95\% CI, 1.2976-1.8164), SE, 0.12683; Tables S6,S8,S9).

\section{Discussion}

This study discovered the correlation of some clinicopathological factors with treatment response after neoadjuvant therapy in breast cancer. In terms of the response of the primary tumor, patients with a larger tumor size, higher classification of regional lymph nodes, positive PR status, and higher histological grade were less likely to achieve breast pCR. Furthermore, tumors with high Ki67 expression had a greater likelihood of breast pCR than those with low Ki67 expression. In terms of axilla response, when the clinical classification of regional lymph nodes was 
Table 4 Multivariate logistic regression analysis for breast response

\begin{tabular}{|c|c|c|c|c|c|}
\hline Clinicopathological factors & Estimate & SE & Wald & $P$ value & OR (95\% Cl) \\
\hline $\mathrm{T} 1$ & & & & & Ref. \\
\hline $\mathrm{T} 2$ & -1.1841 & 0.3244 & 13.3258 & $0.0003^{\star \star \star}$ & $0.306(0.162-0.578)$ \\
\hline T3 & -1.7059 & 0.4165 & 16.772 & $<0.0001^{\star \star \star}$ & $0.182(0.080-0.411)$ \\
\hline \multicolumn{6}{|l|}{$\mathrm{cN}$} \\
\hline No & & & & & Ref. \\
\hline N1 & -1.077 & 0.238 & 20.4691 & $<0.0001^{\star \star \star}$ & $0.341(0.214-0.543)$ \\
\hline N2-3 & -1.0305 & 0.3829 & 7.2446 & $0.0071^{\star *}$ & $0.357(0.168-0.756)$ \\
\hline \multicolumn{6}{|l|}{ Histological grade } \\
\hline III & -1.5579 & 0.966 & 2.6009 & 0.1068 & $0.211(0.032-1.399)$ \\
\hline Unknown & 1.862 & 0.771 & 5.8328 & $0.0157^{*}$ & $6.437(1.420-29.170)$ \\
\hline \multicolumn{6}{|l|}{ PR status } \\
\hline Negative & & & & & Ref. \\
\hline Positive & -0.9769 & 0.2555 & 14.6251 & $0.0001^{* \star *}$ & $0.376(0.228-0.621)$ \\
\hline \multicolumn{6}{|l|}{ Ki67 expression } \\
\hline Low & & & & & Ref. \\
\hline High & 0.6456 & 0.3017 & 4.5789 & $0.0324^{*}$ & $1.907(1.056-3.445)$ \\
\hline \multicolumn{6}{|l|}{ HER2 } \\
\hline
\end{tabular}

*, $\mathrm{P}<0.05$; ${ }^{* \star}, \mathrm{P}<0.01$; ${ }^{* \star *}, \mathrm{P}<0.001$. SE, standard error; OR, odds ratio; $\mathrm{Cl}$, confidence interval; PR, progesterone receptor; HER2, human epidermal growth factor receptor 2 .

more advanced, pCR was less likely. Meanwhile, clinical regional lymph node status $(\mathrm{cN})$ was found to be associated with the treatment response in both the primary tumor and axillary lymph nodes; in other words, a pCR of both the primary tumor and axillary lymph nodes was more likely to be achieved in patients with $\mathrm{cN}_{0}$ disease.

The primary findings of this study demonstrate that a strong correlation exists between the response of the primary tumor and the axilla response. Specifically, once a breast pCR was achieved in patients with $\mathrm{cT}_{2} \mathrm{~N}_{0}$ disease, invasive ductal histology, and negative $\mathrm{HR}$ (ER and $\mathrm{PR}$ ) status after neoadjuvant chemotherapy, axilla pCR was also highly likely. Moreover, axilla pCR was rarely observed if breast pCR was not achieved among patients with $\mathrm{cT}_{3} \mathrm{~N}_{1-2}$ disease treated with neoadjuvant chemotherapy (treatment course fewer than 5 cycles). It is worth noting that $\mathrm{cN}_{0}$ classification was mined in almost every rule among the association rules analyses between breast $\mathrm{pCR}$ and axilla $\mathrm{pCR}$, which further highlights the considerable importance of this factor in predicting the responses of primary tumors and axillary lymph nodes.

Our findings are generally consistent with those of a previous study reported by Tadros et al. (15) and research performed by Barron et al. (14) For instance, Tadros 
Table 5 Association between clinicopathological factors and axilla response (univariate analysis)

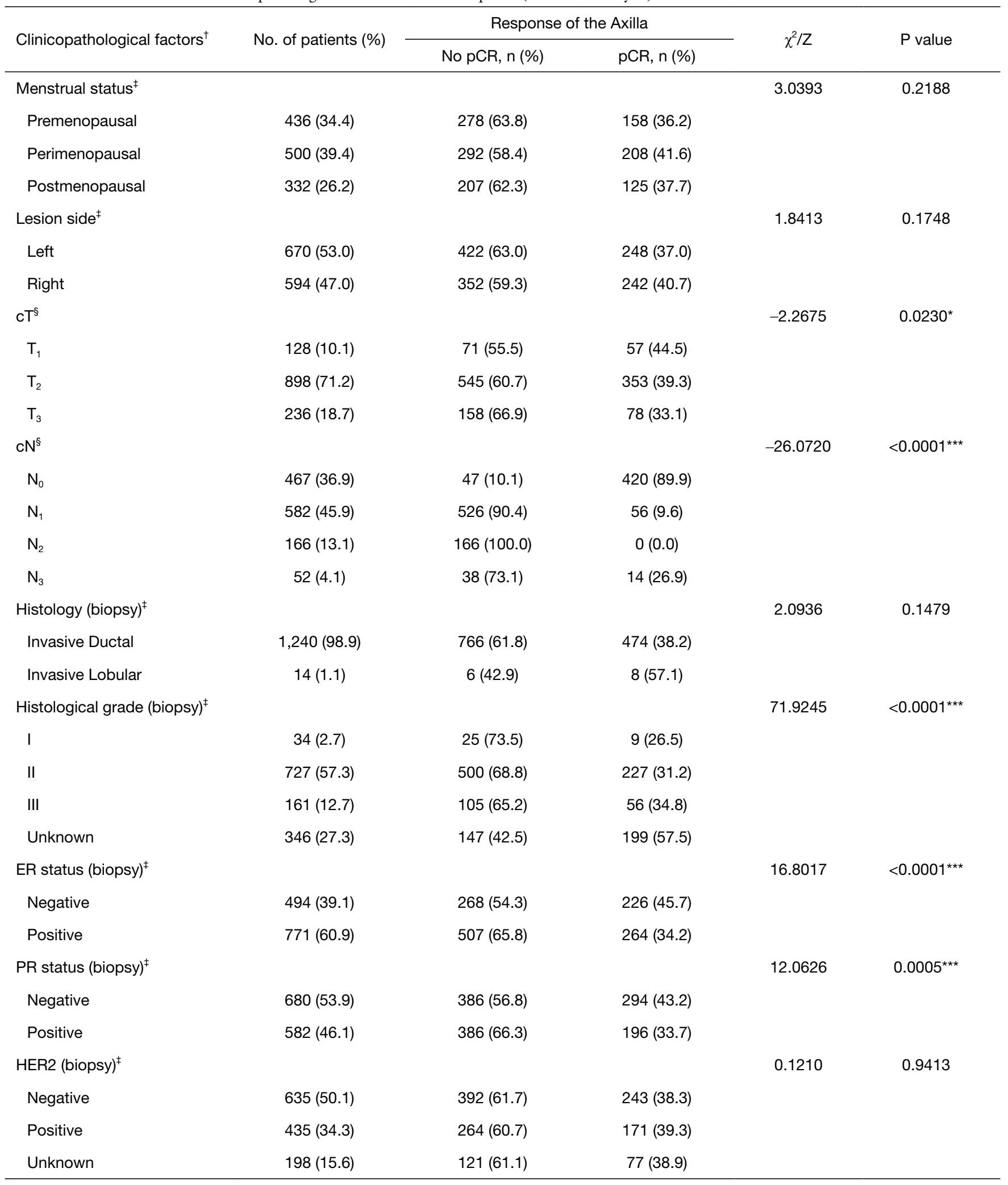

Table 5 (continued) 
Table 5 (continued)

\begin{tabular}{|c|c|c|c|c|c|}
\hline Clinicopathological factors $^{\dagger}$ & No. of patients (\%) & \multicolumn{2}{|c|}{ Response of the Axilla } & $\chi^{2} / Z$ & $P$ value \\
\hline Ki67 expression (biopsy) ${ }^{\ddagger}$ & & & & 7.5982 & $0.0058^{\star \star}$ \\
\hline Low & $346(27.5)$ & $233(67.3)$ & $113(32.7)$ & & \\
\hline High & $914(72.5)$ & $538(58.9)$ & $376(41.1)$ & & \\
\hline$<5$ & $1,175(92.9)$ & 719 (61.2) & $456(38.8)$ & & \\
\hline$\geq 5$ & $90(7.1)$ & $56(62.2)$ & $34(37.8)$ & & \\
\hline Regimen $^{\ddagger}$ & & & & 0.8158 & 0.3664 \\
\hline CT only & 1,242 (98.2) & $763(61.4)$ & $479(38.6)$ & & \\
\hline
\end{tabular}

Table 6 Multivariate logistic regression analysis for axillary response

\begin{tabular}{|c|c|c|c|c|c|}
\hline Clinicopathological Factors & Estimate & SE & Wald & $P$ value & OR $(95 \% \mathrm{Cl})$ \\
\hline No & & & & & Ref. \\
\hline N1 & -4.7699 & 0.2397 & 395.8245 & $<0.0001^{\star \star *}$ & $0.008(0.005-0.014)$ \\
\hline N2-3 & -5.1551 & 0.3444 & 224.0889 & $<0.0001^{\star \star \star}$ & $0.006(0.003-0.011)$ \\
\hline I & & & & & Ref. \\
\hline II & 1.2373 & 0.5821 & 4.5185 & $0.0335^{\star}$ & $3.446(1.101-10.784)$ \\
\hline III & 1.5913 & 0.6468 & 6.0532 & 6.0532 & $4.910(1.382-17.443)$ \\
\hline Unknown & 2.7556 & 0.6098 & 20.4238 & $<0.0001^{\star \star \star}$ & $15.731(4.761-51.974)$ \\
\hline
\end{tabular}

et al. (15) concluded that breast pCR was strongly associated with pathologic nodal status after neoadjuvant therapy and the risk for missing nodal metastases without axillary surgery in selected population (TNBC and HER2-positive breast cancer) was extremely low. Furthermore, Barron et al. (14) pointed out that the highest rates of breast pCR were found in HER2-positive disease and TNBC, and the pathologic nodal positivity rate was extremely low in patients with $\mathrm{cN}_{0}$ HER2-positive disease or TNBC with breast pCR. Both of these studies strengthen the significance of $\mathrm{cN}_{0}$ disease in the correlation between breast
pCR and axilla pCR, and highlight that clinical examination and assessment play a significant role and can indicate the response of axillary lymph nodes. Nevertheless, accurate clinical examination relies on the experience and ability of doctors. Therefore, clinical practitioners should master comprehensive knowledge and improve their personal skills.

Although Kuerer et al. pointed out that the treatment responses of the breast and axilla were inclined to be consistent (13), our findings show that there was inconsistency between these two lesions. The most likely potential factors accounting for such inconsistency were HR-positive (ER- 
Table 7 Association rules analysis between breast pCR and axillary response ${ }^{\dagger}$

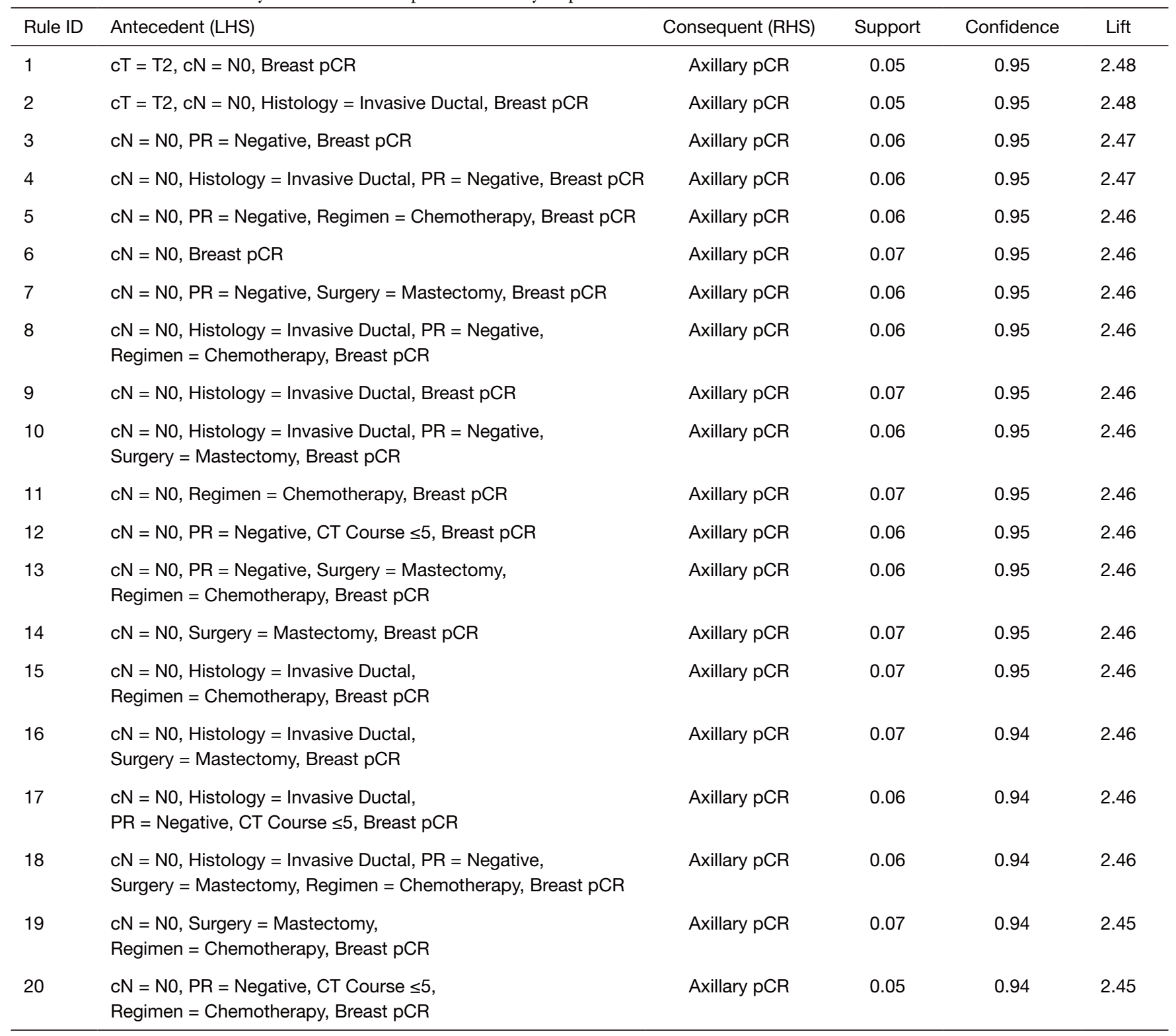

${ }^{\dagger}$, top 20 rules sorted by confidence and lift. support, the frequency of one rule occurrence in the total dataset; confidence, the probability of the RHS in cases of fulfilling the LHS, thus reflecting the reliability of the inference drawn by that rule (LHS $\rightarrow$ RHS); lift, the realistic probability of co-occurrence of LHS and RHS in a rule divided by the expected probability of LHS and RHS co-occurring, assuming that both of them are independent, as a measure of significance. LHS, left-hand-side; RHS, right-hand-side; pCR, pathologic complete response; ER, estrogen receptor; PR, progesterone receptor; CT, chemotherapy. Association rules mining was conducted under the condition that the LHS for breast response was set as 'Breast pCR' while the RHS for axillary response was with no restriction.

positive, PR-positive), HER2-negative, and low Ki67 expression (i.e., luminal A subtype). More importantly, such a finding is in accordance with those of previous studies which suggested that patients with the luminal A subtype were less likely to achieve pCR (in that case, pCR was defined as both the responses of the primary tumor and axillary lymph nodes were confirmed to be pCR) after neoadjuvant therapy than those with HER2-positive or TNBC disease $(8,9)$. However, to the best of our knowledge, this is the first study showing that the responses of the primary tumor and axillary lymph 
nodes were obviously different in breast cancer with a luminal A subtype by analyzing these two lesions independently, which can be regarded as an advancement of previous studies $(8,9)$. Combined with results from the univariate analysis and multivariate logistic regression analysis above, such luminal A baseline characteristics were more likely to influence the response of the primary tumor. Instead, axilla response was shown to be associated with clinical regional lymph nodes classification. Therefore, it is necessary to investigate the potential mechanisms behind these phenomena above in further studies.

The research teams from MD Anderson Cancer Center believe that the consideration regarding omission of axillary surgery in exceptional responders after neoadjuvant chemotherapy is reasonable $(14,15)$. Along with the findings from this study, we agree that selecting a proportion of exceptional responders as candidates for omission of axillary surgery on the basis of accurate evaluation of the primary breast tumor is feasible. Further studies and trials are desperately needed in order to build a model for predicting axillary response through accurate evaluation of the response of the breast. Therefore, our study also sets the stage for the selection of potential participants for trials concerning the safe omission of axillary surgery to improve the QOL of Chinese breast cancer patients.

Of note, our study also investigated the current situation in a comprehensive breast cancer institution in western China with different populations and treatment regimens, and can serve as a reference for broader comparisons between different countries and nations.

One of the most valuable strengths of this study is its use of association rules mining to evaluate correlations. To our knowledge, this is the first time this method, which has a positive impact on data mining and can serve as a reference for future studies, has been utilized in this field. Our definition of neoadjuvant therapy, which included chemotherapy and endocrine therapy rather than neoadjuvant chemotherapy only, was another merit of this study. Rigorous statistical methods were used to mitigate potential heterogeneity by excluding groups with a small sample size from analysis, making groups more comparable. However, the current study undoubtedly has limitations, despite it being well designed and employing strict statistical methods for analyses. Firstly, there is no doubt that data loss has affected the interpretation of the results. Secondly, the sample size of this study was not very large. Thirdly, due to the single-centered and retrospective nature of our study, selection bias in the study population and recall bias in data collection might have unavoidably been introduced. Therefore, replication of these findings through large-scale multicenter studies with other comprehensive breast cancer institutions is necessary.

This is the first study to attempt to identify candidates for the omission of axillary surgery in order to eventually improve the QOL of Chinese breast cancer patients. The findings and research methods of this study not only have implications for the treatment of breast cancer in China, but they could potentially serve as a reference for different countries and regions. However, there is still a long way to go to improve the QOL among patients, and further work should concentrate on cultivating better clinical skills to facilitate more accurate assessment of the disease, as well as strengthening international cooperation in this area. Finally, more multi-centered and transnational randomized controlled trials are needed for best evidence to guide practice that conforms to the requirements of precision medicine and brings more and more benefits to patients.

\section{Conclusions}

In breast cancer patients, clinicopathological factors including primary tumor size, regional lymph nodes, PR status, Ki67 expression, and histological grade were found to be associated with the treatment response of the primary tumor. In regard to the treatment response of the axilla, clinical classification of lymph nodes and histological grade were identified to be the potential influencing factors.

Importantly, our findings suggest a strong correlation between breast pCR and axilla pCR among patients with specific characteristics $\left(\mathrm{cT}_{2} \mathrm{~N}_{0}\right.$ disease, negative $\mathrm{HR}$ status). Furthermore, axilla pCR was rarely observed if breast pCR was not achieved among patients with $c \mathrm{~T}_{3} \mathrm{~N}_{1-2}$ disease. The factors that were most likely to account for the inconsistency between the response of the breast and the axillary lymph nodes were found to be HR-positive, HER2-negative, and low Ki67 expression. Further studies are needed to build a model to predict axillary response by accurately evaluating the response of the breast first.

\section{Acknowledgments}

The authors are grateful to Professor Xiaoni Zhong, from the School of Public Health and Management in Chongqing Medical University, for the critical contributions to the statistical design and analysis in this study. We also thank AME Editing Service for the extensive English language 
editing of this paper.

Funding: This work was supported by grants from the National Natural Science Foundation of China (No.81772979 and 81472658). The funders of the study had no role in study design, data collection, data analysis, data interpretation, or the writing of the report.

\section{Footnote}

Reporting Checklist: The authors have completed the STROBE reporting checklist. Available at http://dx.doi. org/10.21037/gs-20-686

Data Sharing Statement: Available at http://dx.doi. org/10.21037/gs-20-686

Conflicts of Interest: All authors have completed the ICMJE uniform disclosure form (available at http://dx.doi. org/10.21037/gs-20-686). The authors have no conflicts of interest to declare.

Ethical Statement: The authors are accountable for all aspects of the work in ensuring that questions related to the accuracy or integrity of any part of the work are appropriately investigated and resolved. The study was conducted in accordance with the Declaration of Helsinki (as revised in 2013). The institutional ethics committee of the First Affiliated Hospital of Chongqing Medical University reviewed and approved this study (No. 2020-59). Due to the retrospective nature of the research and the concealment of patient information, the need for informed consent was waived.

Open Access Statement: This is an Open Access article distributed in accordance with the Creative Commons Attribution-NonCommercial-NoDerivs 4.0 International License (CC BY-NC-ND 4.0), which permits the noncommercial replication and distribution of the article with the strict proviso that no changes or edits are made and the original work is properly cited (including links to both the formal publication through the relevant DOI and the license). See: https://creativecommons.org/licenses/by-nc-nd/4.0/.

\section{References}

1. Siegel RL, Miller KD, Jemal A. Cancer statistics, 2020. CA Cancer J Clin 2020;70:7-30.

2. Mamtani A, Barrio AV, King TA, et al. How Often Does

(c) Gland Surgery. All rights reserved.
Neoadjuvant Chemotherapy Avoid Axillary Dissection in Patients With Histologicalally Confirmed Nodal Metastases? Results of a Prospective Study. Ann Surg Oncol 2016;23:3467-74.

3. Kaufmann M, von Minckwitz G, Bear HD, et al. Recommendations from an international expert panel on the use of neoadjuvant (primary) systemic treatment of operable breast cancer: new perspectives 2006. Ann Oncol 2007;18:1927-34.

4. Schwartz GF, Hortobagyi GN. Proceedings of the consensus conference on neoadjuvant chemotherapy in carcinoma of the breast, April 26-28, 2003, Philadelphia, Pennsylvania. Cancer 2004;100:2512-32.

5. Shannon C, Smith I. Is there still a role for neoadjuvant therapy in breast cancer? Crit Rev Oncol Hematol 2003;45:77-90.

6. Prowell TM, Pazdur R. Pathological complete response and accelerated drug approval in early breast cancer. $\mathrm{N}$ Engl J Med 2012;366:2438-41.

7. Cortazar P, Zhang L, Untch M, et al. Pathological complete response and long-term clinical benefit in breast cancer: the CTNeoBC pooled analysis. Lancet 2014;384:164-72.

8. van la Parra RF, Kuerer HM. Selective elimination of breast cancer surgery in exceptional responders: historical perspective and current trials. Breast Cancer Res 2016;18:28.

9. Guarneri V, Broglio K, Kau SW, et al. Prognostic value of pathologic complete response after primary chemotherapy in relation to hormone receptor status and other factors. J Clin Oncol 2006;24:1037-44.

10. von Minckwitz G, Untch M, Blohmer JU, et al. Definition and impact of pathologic complete response on prognosis after neoadjuvant chemotherapy in various intrinsic breast cancer subtypes. J Clin Oncol 2012;30:1796-804.

11. Houssami N, Macaskill P, von Minckwitz G, et al. Metaanalysis of the association of breast cancer subtype and pathologic complete response to neoadjuvant chemotherapy. Eur J Cancer 2012;48:3342-54.

12. Kwan W, Jackson J, Weir LM, et al. Chronic arm morbidity after curative breast cancer treatment: prevalence and impact on quality of life. J Clin Oncol 2002;20:4242-8.

13. Kuerer HM, Sahin AA, Hunt KK, et al. Incidence and impact of documented eradication of breast cancer axillary lymph node metastases before surgery in patients treated with neoadjuvant chemotherapy. Ann Surg 1999;230:72-8.

14. Barron AU, Hoskin TL, Day CN, et al. Association 
of Low Nodal Positivity Rate Among Patients With ERBB2-Positive or Triple-Negative Breast Cancer and Breast Pathologic Complete Response to Neoadjuvant Chemotherapy. JAMA Surg 2018;153:1120-6.

15. Tadros AB, Yang WT, Krishnamurthy $S$, et al. Identification of Patients With Documented Pathologic Complete Response in the Breast After Neoadjuvant Chemotherapy for Omission of Axillary Surgery. JAMA Surg 2017;152:665-70.

16. Hosmer DW, Lemeshow S. Model-Building Strategies and Methods for Logistic Regression. In: Shewhart WA, Wilks SS, eds. Applied Logistic Regression, 2nd edition: John Wiley \& Sons, 2000:91-142.

17. Agrawal R, Srikant R. Fast Algorithms for Mining Association Rules in Large Databases. In: Proceedings of the 20th International Conference on Very Large Data Bases, 1994.

Cite this article as: Wang $\mathrm{Y}, \mathrm{Li} \mathrm{L}$, Liu X, Wang Y, Tang Z, Wu Y, Jin Y, Liu S. Treatment response correlation between primary tumor and axillary lymph nodes after neoadjuvant therapy in breast cancer: a retrospective study based on realworld data. Gland Surg 2021;10(2):656-669. doi: 10.21037/gs20-686
18. Vougas K, Sakellaropoulos T, Kotsinas A, et al. Machine learning and data mining frameworks for predicting drug response in cancer: An overview and a novel in silico screening process based on association rule mining. Pharmacol Ther 2019;203:107395.

19. Hornik K, Grün B, Hahsler M. arules - A Computational Environment for Mining Association Rules and Frequent Item Sets. J Stat Softw 2005;14:1-25.

20. Amin MB, Edge S, Greene F, et al. AJCC Cancer Staging Manual, Eight Edition. New York: Springer, 2017.

21. Ogston KN, Miller ID, Payne S, et al. A new histological grading system to assess response of breast cancers to primary chemotherapy: prognostic significance and survival. Breast 2003;12:320-7.

22. Eisenhauer EA, Therasse P, Bogaerts J, et al. New response evaluation criteria in solid tumours: revised RECIST guideline (version 1.1). Eur J Cancer 2009;45:228-47. 
Table S1 Association rules analysis between breast pCR and axillary response (totally 57 rules)

\begin{tabular}{|c|c|c|c|c|c|}
\hline Rule ID & Antecedent (LHS) & Consequent (RHS) & Support & Confidence & Lift \\
\hline 1 & $\mathrm{cT}=\mathrm{T} 2, \mathrm{cN}=\mathrm{NO}$, Breast $\mathrm{pCR}$ & Axillary pCR & 0.05 & 0.95 & 2.48 \\
\hline 2 & $\mathrm{cT}=\mathrm{T} 2, \mathrm{cN}=\mathrm{N} 0$, Histology = Invasive Ductal, Breast $\mathrm{pCR}$ & Axillary pCR & 0.05 & 0.95 & 2.48 \\
\hline 3 & $\mathrm{cN}=\mathrm{N} 0, \mathrm{PR}=$ Negative, Breast $\mathrm{pCR}$ & Axillary $\mathrm{pCR}$ & 0.06 & 0.95 & 2.47 \\
\hline 4 & $\mathrm{cN}=\mathrm{NO}$, Histology $=$ Invasive Ductal, $\mathrm{PR}=$ Negative, Breast $\mathrm{pCR}$ & Axillary pCR & 0.06 & 0.95 & 2.47 \\
\hline 5 & $\mathrm{cN}=\mathrm{NO}, \mathrm{PR}=$ Negative, Regimen $=$ Chemotherapy, Breast $\mathrm{pCR}$ & Axillary pCR & 0.06 & 0.95 & 2.46 \\
\hline 6 & $\mathrm{cN}=\mathrm{NO}$, Breast pCR & Axillary pCR & 0.07 & 0.95 & 2.46 \\
\hline 7 & $\mathrm{cN}=\mathrm{NO}, \mathrm{PR}=$ Negative, Surgery $=$ Mastectomy, Breast $\mathrm{pCR}$ & Axillary $\mathrm{pCR}$ & 0.06 & 0.95 & 2.46 \\
\hline 8 & $\mathrm{cN}=\mathrm{N} 0$, Histology $=$ Invasive Ductal, $\mathrm{PR}=$ Negative, Regimen $=$ Chemotherapy, Breast $\mathrm{pCR}$ & Axillary pCR & 0.06 & 0.95 & 2.46 \\
\hline 9 & $\mathrm{cN}=\mathrm{N} 0$, Histology $=$ Invasive Ductal, Breast pCR & Axillary pCR & 0.07 & 0.95 & 2.46 \\
\hline 10 & $\mathrm{cN}=\mathrm{N} 0$, Histology = Invasive Ductal, $\mathrm{PR}=$ Negative, Surgery = Mastectomy, Breast $\mathrm{pCR}$ & Axillary pCR & 0.06 & 0.95 & 2.46 \\
\hline 11 & $\mathrm{cN}=\mathrm{N} 0$, Regimen $=$ Chemotherapy, Breast pCR & Axillary pCR & 0.07 & 0.95 & 2.46 \\
\hline 12 & $\mathrm{cN}=\mathrm{N} 0, \mathrm{PR}=$ Negative, $\mathrm{CT}$ Course $\leq 5$, Breast $\mathrm{pCR}$ & Axillary pCR & 0.06 & 0.95 & 2.46 \\
\hline 13 & $\mathrm{cN}=\mathrm{NO}, \mathrm{PR}=$ Negative, Surgery $=$ Mastectomy, Regimen = Chemotherapy, Breast $\mathrm{pCR}$ & Axillary pCR & 0.06 & 0.95 & 2.46 \\
\hline 14 & $\mathrm{cN}=\mathrm{N} 0$, Surgery $=$ Mastectomy, Breast $\mathrm{pCR}$ & Axillary $\mathrm{pCR}$ & 0.07 & 0.95 & 2.46 \\
\hline 15 & $\mathrm{cN}=\mathrm{N} 0$, Histology = Invasive Ductal, Regimen = Chemotherapy, Breast pCR & Axillary pCR & 0.07 & 0.95 & 2.46 \\
\hline 16 & $\mathrm{cN}=\mathrm{NO}$, Histology = Invasive Ductal, Surgery = Mastectomy, Breast pCR & Axillary pCR & 0.07 & 0.94 & 2.46 \\
\hline 17 & $\mathrm{cN}=\mathrm{N} 0$, Histology $=$ Invasive Ductal, $\mathrm{PR}=$ Negative, $\mathrm{CT}$ Course $\leq 5$, Breast $\mathrm{pCR}$ & Axillary pCR & 0.06 & 0.94 & 2.46 \\
\hline 18 & $\mathrm{cN}=\mathrm{N} 0$, Histology = Invasive Ductal, $\mathrm{PR}=$ Negative, Surgery = Mastectomy, Regimen = Chemotherapy, Breast pCR & Axillary pCR & 0.06 & 0.94 & 2.46 \\
\hline 19 & $\mathrm{cN}=\mathrm{N} 0$, Surgery $=$ Mastectomy, Regimen $=$ Chemotherapy, Breast $\mathrm{pCR}$ & Axillary pCR & 0.07 & 0.94 & 2.45 \\
\hline 20 & $\mathrm{cN}=\mathrm{N} 0, \mathrm{PR}=$ Negative, $\mathrm{CT}$ Course $\leq 5$, Regimen $=$ Chemotherapy, Breast $\mathrm{pCR}$ & Axillary pCR & 0.05 & 0.94 & 2.45 \\
\hline 21 & $\mathrm{cN}=\mathrm{NO}, \mathrm{CT}$ Course $\leq 5$, Breast pCR & Axillary pCR & 0.07 & 0.94 & 2.45 \\
\hline 22 & $\mathrm{cN}=\mathrm{N} 0$, Histology = Invasive Ductal, Surgery = Mastectomy, Regimen = Chemotherapy, Breast pCR & Axillary pCR & 0.07 & 0.94 & 2.45 \\
\hline 23 & $\mathrm{cN}=\mathrm{N} 0, \mathrm{PR}=$ Negative, $\mathrm{CT}$ Course $\leq 5$, Surgery $=$ Mastectomy, Breast $\mathrm{pCR}$ & Axillary pCR & 0.05 & 0.94 & 2.45 \\
\hline 24 & $\mathrm{cN}=\mathrm{N} 0$, Histology = Invasive Ductal, $\mathrm{PR}=$ Negative, $\mathrm{CT}$ Course $\leq 5$, Regimen $=$ Chemotherapy, Breast $\mathrm{pCR}$ & Axillary pCR & 0.05 & 0.94 & 2.45 \\
\hline 25 & $\mathrm{cN}=\mathrm{N} 0$, Histology $=$ Invasive Ductal, $\mathrm{CT}$ Course $\leq 5$, Breast pCR & Axillary pCR & 0.07 & 0.94 & 2.45 \\
\hline 26 & $\mathrm{cN}=\mathrm{N} 0, \mathrm{PR}=$ Negative, Ki67 Expression $=$ High, Breast $\mathrm{pCR}$ & Axillary pCR & 0.05 & 0.94 & 2.45 \\
\hline 27 & $\mathrm{cN}=\mathrm{N} 0$, Histology = Invasive Ductal, $\mathrm{PR}=$ Negative, $\mathrm{CT}$ Course $\leq 5$, Surgery = Mastectomy, Breast $\mathrm{pCR}$ & Axillary pCR & 0.05 & 0.94 & 2.45 \\
\hline 28 & $\mathrm{cN}=\mathrm{N} 0, \mathrm{CT}$ Course $\leq 5$, Regimen = Chemotherapy, Breast pCR & Axillary $\mathrm{pCR}$ & 0.07 & 0.94 & 2.45 \\
\hline 29 & $\mathrm{cN}=\mathrm{N0}, \mathrm{Ki67}$ Expression $=$ High, Breast pCR & Axillary pCR & 0.07 & 0.94 & 2.45 \\
\hline 30 & $\mathrm{cN}=\mathrm{N} 0, \mathrm{CT}$ Course $\leq 5$, Surgery $=$ Mastectomy, Breast $\mathrm{pCR}$ & Axillary pCR & 0.07 & 0.94 & 2.45 \\
\hline 31 & $\mathrm{cN}=\mathrm{N} 0$, Histology $=$ Invasive Ductal, $\mathrm{PR}=$ Negative, $\mathrm{CT}$ Course $\leq 5, \mathrm{Ki67}$ Expression $=$ High, Breast $\mathrm{pCR}$ & Axillary pCR & 0.05 & 0.94 & 2.45 \\
\hline 32 & $\mathrm{cN}=$ N0, Histology = Invasive Ductal, CT Course $\leq 5$, Regimen = Chemotherapy, Breast pCR & Axillary pCR & 0.07 & 0.94 & 2.45 \\
\hline 33 & $\mathrm{cN}=\mathrm{N} 0, \mathrm{PR}=$ Negative, $\mathrm{CT}$ Course $\leq 5$, Surgery = Mastectomy, Regimen = Chemotherapy, Breast $\mathrm{pCR}$ & Axillary pCR & 0.05 & 0.94 & 2.45 \\
\hline 34 & $\mathrm{cN}=\mathrm{N} 0$, Histology $=$ Invasive Ductal, Ki67 Expression = High, Breast pCR & Axillary $\mathrm{pCR}$ & 0.06 & 0.94 & 2.45 \\
\hline 35 & $\mathrm{cN}=\mathrm{N} 0$, Histology = Invasive Ductal, $\mathrm{CT}$ Course $\leq 5$, Surgery = Mastectomy, Breast pCR & Axillary pCR & 0.06 & 0.94 & 2.45 \\
\hline 36 & $\mathrm{cN}=\mathrm{N0}, \mathrm{PR}=$ Negative, Ki67 Expression = High, Regimen = Chemotherapy, Breast pCR & Axillary pCR & 0.05 & 0.94 & 2.45 \\
\hline 37 & $\mathrm{cN}=\mathrm{N} 0$, Histology = Invasive Ductal, $\mathrm{PR}=$ Negative, $\mathrm{CT}$ Course $\leq 5$, Surgery = Mastectomy, Regimen = Chemotherapy, Breast pCR & Axillary pCR & 0.05 & 0.94 & 2.45 \\
\hline 38 & $\mathrm{cN}=$ N0, Ki67 Expression = High, Regimen = Chemotherapy, Breast pCR & Axillary pCR & 0.06 & 0.94 & 2.44 \\
\hline 39 & $\mathrm{cN}=\mathrm{N} 0, \mathrm{CT}$ Course $\leq 5$, Surgery $=$ Mastectomy, Regimen $=$ Chemotherapy, Breast $\mathrm{pCR}$ & Axillary pCR & 0.06 & 0.94 & 2.44 \\
\hline 40 & $\mathrm{cN}=\mathrm{N} 0, \mathrm{PR}=$ Negative, Ki67 Expression $=$ High, Surgery $=$ Mastectomy, Breast $\mathrm{pCR}$ & Axillary pCR & 0.05 & 0.94 & 2.44 \\
\hline 41 & $\mathrm{cN}=\mathrm{N} 0$, Histology $=$ Invasive Ductal, $\mathrm{PR}=$ Negative, Ki67 Expression $=$ High, Regimen = Chemotherapy, Breast pCR & Axillary pCR & 0.05 & 0.94 & 2.44 \\
\hline 42 & $\mathrm{cN}=\mathrm{N0}, \mathrm{Ki67}$ Expression $=$ High, Surgery = Mastectomy, Breast pCR & Axillary pCR & 0.06 & 0.94 & 2.44 \\
\hline 43 & $\mathrm{cN}=\mathrm{N} 0$, Histology $=$ Invasive Ductal, Ki67 Expression = High, Regimen = Chemotherapy, Breast pCR & Axillary pCR & 0.06 & 0.94 & 2.44 \\
\hline 44 & $\mathrm{cN}=$ N0, Histology = Invasive Ductal, $\mathrm{CT}$ Course $\leq 5$, Surgery = Mastectomy, Regimen = Chemotherapy, Breast pCR & Axillary pCR & 0.06 & 0.94 & 2.44 \\
\hline 45 & $\mathrm{cN}=$ N0, Histology = Invasive Ductal, Ki67 Expression = High, Surgery = Mastectomy, Breast pCR & Axillary pCR & 0.06 & 0.94 & 2.44 \\
\hline 46 & $\mathrm{cN}=$ N0, Ki67 Expression $=$ High, Surgery $=$ Mastectomy, Regimen = Chemotherapy, Breast pCR & Axillary $\mathrm{pCR}$ & 0.06 & 0.94 & 2.44 \\
\hline 47 & $\mathrm{cN}=\mathrm{N0}, \mathrm{Ki67}$ Expression $=$ High, $\mathrm{CT}$ Course $\leq 5$, Breast pCR & Axillary pCR & 0.06 & 0.94 & 2.44 \\
\hline 48 & $\mathrm{cN}=$ N0, Histology = Invasive Ductal, Ki67 Expression = High, Surgery = Mastectomy, Regimen = Chemotherapy, Breast pCR & Axillary pCR & 0.06 & 0.94 & 2.44 \\
\hline 49 & $\mathrm{cN}=\mathrm{N0}$, Histology = Invasive Ductal, Ki67 Expression = High, CT Course $\leq 5$, Breast pCR & Axillary pCR & 0.06 & 0.94 & 2.43 \\
\hline 50 & $\mathrm{cN}=$ N0, Ki67 Expression $=$ High, $\mathrm{CT}$ Course $\leq 5$, Regimen = Chemotherapy, Breast pCR & Axillary $\mathrm{pCR}$ & 0.06 & 0.94 & 2.43 \\
\hline 51 & $\mathrm{cN}=$ N0, Ki67 Expression $=$ High, $\mathrm{CT}$ Course $\leq 5$, Surgery = Mastectomy, Breast pCR & Axillary $\mathrm{pCR}$ & 0.06 & 0.93 & 2.43 \\
\hline 52 & $\mathrm{cN}=\mathrm{N} 0$, Histology $=$ Invasive Ductal, Ki67 Expression $=$ High, CT Course $\leq 5$, Regimen $=$ Chemotherapy, Breast pCR & Axillary pCR & 0.06 & 0.93 & 2.43 \\
\hline 53 & $\mathrm{cN}=$ N0, Histology = Invasive Ductal, Ki67 Expression = High, CT Course $\leq 5$, Surgery = Mastectomy, Breast pCR & Axillary pCR & 0.06 & 0.93 & 2.43 \\
\hline 54 & $\mathrm{cN}=$ N0, Ki67 Expression $=$ High, $\mathrm{CT}$ Course $\leq 5$, Surgery = Mastectomy, Regimen = Chemotherapy, Breast pCR & Axillary pCR & 0.06 & 0.93 & 2.43 \\
\hline 55 & $\mathrm{cN}=$ N0, Histology = Invasive Ductal, Ki67 Expression = High, CT Course $\leq 5$, Surgery = Mastectomy, Regimen = Chemotherapy, Breast pCR & Axillary pCR & 0.06 & 0.93 & 2.42 \\
\hline 56 & $E R=$ Negative,$P R=$ Negative, Breast $p C R$ & Axillary pCR & 0.05 & 0.75 & 1.95 \\
\hline 57 & Histology $=$ Invasive Ductal, $E R=$ Negative, $\mathrm{PR}=$ Negative, Breast $\mathrm{pCR}$ & Axillary pCR & 0.05 & 0.75 & 1.95 \\
\hline
\end{tabular}

$\mathrm{pCR}$, pathologic complete response; $\mathrm{ER}$, estrogen receptor; $\mathrm{PR}$, progesterone receptor; $\mathrm{CT}$, chemotherapy. 


\begin{tabular}{|c|c|c|c|c|c|}
\hline Rule ID & Antecedent (LHS) & Consequent (RHS) & Support & Confidence & Lift \\
\hline 1 & $\mathrm{cN}=\mathrm{N} 2, \mathrm{No} \mathrm{pCR}$ in the Breast & No $p C R$ in the Axilla & 0.13 & 1.00 & 1.62 \\
\hline 2 & $\mathrm{cN}=\mathrm{N} 2$, Surgery = Mastectomy, No pCR in the Breast & No $p C R$ in the Axilla & 0.13 & 1.00 & 1.62 \\
\hline 3 & $\mathrm{cN}=\mathrm{N} 2$, Regimen $=$ Chemotherapy, No $\mathrm{pCR}$ in the Breast & No pCR in the Axilla & 0.13 & 1.00 & 1.62 \\
\hline 4 & $\mathrm{cN}=\mathrm{N} 2$, Histology = Invasive Ductal, No pCR in the Breast & No pCR in the Axilla & 0.13 & 1.00 & 1.62 \\
\hline 5 & $\mathrm{cN}=\mathrm{N} 2$, Surgery = Mastectomy, Regimen $=$ Chemotherapy, No pCR in the Breast & No $p C R$ in the Axilla & 0.13 & 1.00 & 1.62 \\
\hline 6 & $\mathrm{cN}=\mathrm{N} 2$, Histology = Invasive Ductal, Surgery = Mastectomy, No pCR in the Breast & No $p C R$ in the Axilla & 0.13 & 1.00 & 1.62 \\
\hline 7 & $\mathrm{cN}=\mathrm{N} 2$, Histology = Invasive Ductal, Regimen = Chemotherapy, No pCR in the Breast & No pCR in the Axilla & 0.13 & 1.00 & 1.62 \\
\hline 8 & $\mathrm{cN}=\mathrm{N} 2$, Histology = Invasive Ductal, Surgery = Mastectomy, Regimen = Chemotherapy, No pCR in the Breast & No pCR in the Axilla & 0.13 & 1.00 & 1.62 \\
\hline 9 & $\mathrm{cN}=\mathrm{N} 2, \mathrm{CT}$ Course $\leq 5$, No $\mathrm{pCR}$ in the Breast & No pCR in the Axilla & 0.12 & 1.00 & 1.62 \\
\hline 10 & $\mathrm{cN}=\mathrm{N} 2, \mathrm{CT}$ Course $\leq 5$, Surgery = Mastectomy, No pCR in the Breast & No $p C R$ in the Axilla & 0.12 & 1.00 & 1.62 \\
\hline
\end{tabular}

LHS, left-hand-side; RHS, right-hand-side; pCR, pathologic complete response; CT, chemotherapy.

Table S3 Association rules analysis between no pCR in the breast and response in the axilla (top 10 rules sorted by support from 4,567 rules totally)

\begin{tabular}{|c|c|c|c|c|c|}
\hline Rule ID & Antecedent (LHS) & Consequent (RHS) & Support & Confidence & Lift \\
\hline 1 & $\mathrm{cN}=\mathrm{N} 1$, No $\mathrm{pCR}$ in the Breast & No $p C R$ in the Axilla & 0.39 & 0.91 & 1.48 \\
\hline 2 & $\mathrm{cN}=\mathrm{N} 1$, Regimen $=$ Chemotherapy, No pCR in the Breast & No $p C R$ in the Axilla & 0.39 & 0.92 & 1.49 \\
\hline 3 & $\mathrm{cN}=\mathrm{N} 1$, Histology $=$ Invasive Ductal, No pCR in the Breast & No $p C R$ in the Axilla & 0.39 & 0.91 & 1.48 \\
\hline 4 & $\mathrm{cN}=\mathrm{N} 1$, Histology $=$ Invasive Ductal, Regimen $=$ Chemotherapy, No pCR in the Breast & No $p C R$ in the Axilla & 0.38 & 0.92 & 1.49 \\
\hline 5 & $\mathrm{cN}=\mathrm{N} 1$, Surgery $=$ Mastectomy, No pCR in the Breast & No pCR in the Axilla & 0.38 & 0.91 & 1.48 \\
\hline 6 & $\mathrm{cN}=\mathrm{N} 1$, Surgery $=$ Mastectomy, Regimen $=$ Chemotherapy, No pCR in the Breast & No $p C R$ in the Axilla & 0.38 & 0.92 & 1.49 \\
\hline 7 & $\mathrm{cN}=\mathrm{N} 1$, Histology $=$ Invasive Ductal, Surgery $=$ Mastectomy, No pCR in the Breast & No pCR in the Axilla & 0.38 & 0.91 & 1.48 \\
\hline 8 & $\mathrm{cN}=\mathrm{N} 1$, Histology $=$ Invasive Ductal, Surgery = Mastectomy, Regimen = Chemotherapy, No pCR in the Breast & No pCR in the Axilla & 0.38 & 0.92 & 1.49 \\
\hline 9 & $\mathrm{cN}=\mathrm{N} 1, \mathrm{CT}$ Course $\leq 5$, No $\mathrm{pCR}$ in the Breast & No $p C R$ in the Axilla & 0.36 & 0.91 & 1.49 \\
\hline 10 & $\mathrm{cN}=\mathrm{N} 1, \mathrm{CT}$ Course $\leq 5$, Regimen $=$ Chemotherapy, No pCR in the Breast & No $p C R$ in the Axilla & 0.36 & 0.92 & 1.49 \\
\hline
\end{tabular}

LHS, left-hand-side; RHS, right-hand-side; $\mathrm{PCR}$, pathologic complete response; $\mathrm{CT}$, chemotherapy.

\begin{tabular}{|c|c|c|c|c|c|}
\hline Rule ID & Antecedent (LHS) & Consequent (RHS) & Support & Confidence & Lift \\
\hline 1 & $\mathrm{cT}=\mathrm{T} 3, \mathrm{HER} 2=$ Negative, No $\mathrm{pCR}$ in the Axilla & No $\mathrm{pCR}$ in the Breast & 0.07 & 1.00 & 1.13 \\
\hline 2 & Menstrual Status $=$ Postmenopausal, Ki67 $=$ Low Expression, No pCR in the Axilla & No $\mathrm{pCR}$ in the Breast & 0.05 & 1.00 & 1.13 \\
\hline 3 & $\mathrm{cT}=\mathrm{T} 3, \mathrm{HER} 2=$ Negative, $\mathrm{CT}$ Course $\leq 5$, No $\mathrm{pCR}$ in the Axilla & No $\mathrm{pCR}$ in the Breast & 0.05 & 1.00 & 1.13 \\
\hline 4 & $\mathrm{cT}=\mathrm{T} 3, \mathrm{HER} 2=$ Negative, Surgery $=$ Mastectomy, No pCR in the Axilla & No $\mathrm{pCR}$ in the Breast & 0.07 & 1.00 & 1.13 \\
\hline 5 & $\mathrm{CT}=\mathrm{T} 3, \mathrm{HER} 2=$ Negative, Regimen = Chemotherapy, No pCR in the Axilla & No $\mathrm{pCR}$ in the Breast & 0.07 & 1.00 & 1.13 \\
\hline 6 & $\mathrm{cT}=\mathrm{T} 3$, Histology $=$ Invasive Ductal, $\mathrm{HER} 2=$ Negative, No $\mathrm{pCR}$ in the Axilla & No $\mathrm{pCR}$ in the Breast & 0.06 & 1.00 & 1.13 \\
\hline 7 & Menstrual Status $=$ Postmenopausal, Ki67 = Low Expression, Surgery $=$ Mastectomy, No pCR in the Axilla & No $\mathrm{pCR}$ in the Breast & 0.05 & 1.00 & 1.13 \\
\hline 8 & Menstrual Status $=$ Postmenopausal, Ki67 $=$ Low Expression, Regimen $=$ Chemotherapy, No pCR in the Axilla & No $\mathrm{pCR}$ in the Breast & 0.05 & 1.00 & 1.13 \\
\hline 9 & Menstrual Status $=$ Postmenopausal, Histology $=$ Invasive Ductal, Ki67 = Low Expression, No pCR in the Axilla & No $\mathrm{pCR}$ in the Breast & 0.05 & 1.00 & 1.13 \\
\hline 10 & Menstrual Status $=$ Postmenopausal, $\mathrm{cT}=\mathrm{T} 2, \mathrm{PR}=$ Positive, No $\mathrm{pCR}$ in the Axilla & No pCR in the Breast & 0.05 & 1.00 & 1.13 \\
\hline
\end{tabular}

LHS, left-hand-side; RHS, right-hand-side; HER2, human epidermal growth factor receptor 2; pCR, pathologic complete response; CT, chemotherapy; PR, progesterone receptor.

Table S5 Association rules analysis between no pCR in the axilla and response in the breast (top 10 rules sorted by support from 8008 rules totally)

\begin{tabular}{|c|c|c|c|c|c|}
\hline Rule ID & Antecedent (LHS) & Consequent (RHS) & Support & Confidence & Lift \\
\hline 1 & No pCR in the Axilla & No $p C R$ in the Breast & 0.58 & 0.94 & 1.07 \\
\hline 2 & Histology = Invasive Ductal, No pCR in the Axilla & No $p C R$ in the Breast & 0.57 & 0.94 & 1.07 \\
\hline 3 & Regimen $=$ Chemotherapy, No pCR in the Axilla & No $p C R$ in the Breast & 0.57 & 0.94 & 1.06 \\
\hline 4 & Surgery = Mastectomy, No pCR in the Axilla & No $p C R$ in the Breast & 0.57 & 0.94 & 1.06 \\
\hline 5 & Histology = Invasive Ductal, Regimen = Chemotherapy, No pCR in the Axilla & No $p C R$ in the Breast & 0.56 & 0.94 & 1.06 \\
\hline 6 & Histology = Invasive Ductal, Surgery = Mastectomy, No pCR in the Axilla & No $p C R$ in the Breast & 0.56 & 0.94 & 1.06 \\
\hline 7 & Surgery $=$ Mastectomy, Regimen $=$ Chemotherapy, No pCR in the Axilla & No $p C R$ in the Breast & 0.56 & 0.94 & 1.06 \\
\hline 8 & Histology = Invasive Ductal, Surgery = Mastectomy, Regimen = Chemotherapy, No pCR in the Axilla & No $p C R$ in the Breast & 0.55 & 0.94 & 1.06 \\
\hline 9 & CT Course $\leq 5$, No pCR in the Axilla & No $p C R$ in the Breast & 0.53 & 0.94 & 1.06 \\
\hline 10 & Histology = Invasive Ductal, CT Course $\leq 5$, No pCR in the Axilla & No pCR in the Breast & 0.53 & 0.94 & 1.06 \\
\hline
\end{tabular}

LHS, left-hand-side; RHS, right-hand-side; PCR, pathologic complete response; CT, chemotherapy. 


\begin{tabular}{|c|c|c|c|c|c|}
\hline Rule ID & Antecedent (LHS) & Consequent (RHS) & Support & Confidence & Lift \\
\hline 1 & Lesion Side $=$ Left, $\mathrm{cT}=\mathrm{T} 2, \mathrm{cN}=\mathrm{N} 0, \mathrm{HER} 2=$ Negative, No $\mathrm{pCR}$ in the Breast & Axillary $\mathrm{pCR}$ & 0.05 & 0.97 & 2.53 \\
\hline 2 & Lesion Side $=$ Left, $\mathrm{cT}=\mathrm{T} 2, \mathrm{cN}=\mathrm{N} 0, \mathrm{HER} 2=$ Negative, Regimen $=$ Chemotherapy, No pCR in the Breast & Axillary pCR & 0.05 & 0.97 & 2.53 \\
\hline 3 & Lesion Side = Left, $\mathrm{cT}=\mathrm{T} 2, \mathrm{cN}=\mathrm{N} 0, \mathrm{HER} 2=$ Negative, Surgery $=$ Mastectomy, No pCR in the Breast & Axillary pCR & 0.05 & 0.97 & 2.52 \\
\hline 4 & Lesion Side $=$ Left, $\mathrm{cT}=\mathrm{T} 2, \mathrm{cN}=\mathrm{N} 0, \mathrm{HER} 2=$ Negative, Surgery $=$ Mastectomy, Regimen = Chemotherapy, No $\mathrm{pCR}$ in the Breast & Axillary pCR & 0.05 & 0.97 & 2.52 \\
\hline 5 & Lesion Side $=$ Left, $\mathrm{cT}=\mathrm{T} 2, \mathrm{cN}=$ N0, Histology $=$ Invasive Ductal, HER2 $=$ Negative, No pCR in the Breast & Axillary pCR & 0.05 & 0.97 & 2.52 \\
\hline 6 & Lesion Side $=$ Left, $\mathrm{cT}=\mathrm{T} 2, \mathrm{cN}=$ N0, Histology $=$ Invasive Ductal, HER2 $=$ Negative, Regimen $=$ Chemotherapy, No pCR in the Breast & Axillary $\mathrm{pCR}$ & 0.05 & 0.97 & 2.52 \\
\hline 7 & Lesion Side $=$ Left, $\mathrm{cT}=\mathrm{T} 2, \mathrm{cN}=\mathrm{N} 0$, Histology $=$ Invasive Ductal, HER2 $=$ Negative, Surgery $=$ Mastectomy, No $\mathrm{pCR}$ in the Breast & Axillary pCR & 0.05 & 0.97 & 2.52 \\
\hline 8 & $\begin{array}{l}\text { Lesion Side }=\text { Left, } \mathrm{cT}=\mathrm{T} 2, \mathrm{cN}=\mathrm{N} 0 \text {, Histology }=\text { Invasive Ductal, HER2 }=\text { Negative, Surgery = Mastectomy, Regimen = Chemotherapy, } \\
\text { No } \mathrm{pCR} \text { in the Breast }\end{array}$ & Axillary pCR & 0.05 & 0.97 & 2.52 \\
\hline 9 & Lesion Side $=$ Left, $\mathrm{cT}=\mathrm{T} 2, \mathrm{cN}=\mathrm{N} 0, \mathrm{HER} 2=$ Negative, $\mathrm{CT}$ Course $\leq 5$, No $\mathrm{pCR}$ in the Breast & Axillary pCR & 0.05 & 0.97 & 2.52 \\
\hline 10 & Lesion Side $=$ Left, $c T=T 2, c N=N 0, H E R 2=$ Negative,$C T$ Course $\leq 5$, Regimen $=$ Chemotherapy, No $p C R$ in the Breast & Axillary $\mathrm{pCR}$ & 0.05 & 0.97 & 2.52 \\
\hline
\end{tabular}

LHS, left-hand-side; RHS, right-hand-side; HER2, human epidermal growth factor receptor 2; pCR, pathologic complete response; CT, chemotherapy.

\begin{tabular}{|c|c|c|c|c|c|}
\hline Rule ID & Antecedent (LHS) & Consequent (RHS) & Support & Confidence & Lift \\
\hline 1 & $\mathrm{cN}=\mathrm{NO}, \mathrm{No} \mathrm{pCR}$ in the Breast & Axillary $\mathrm{pCR}$ & 0.26 & 0.89 & 2.32 \\
\hline 2 & $\mathrm{cN}=\mathrm{N} 0$, Regimen $=$ Chemotherapy, No $\mathrm{pCR}$ in the Breast & Axillary $\mathrm{pCR}$ & 0.26 & 0.90 & 2.34 \\
\hline 3 & $\mathrm{cN}=\mathrm{N} 0$, Surgery $=$ Mastectomy, No pCR in the Breast & Axillary $\mathrm{pCR}$ & 0.26 & 0.89 & 2.33 \\
\hline 4 & $\mathrm{cN}=\mathrm{N} 0$, Histology $=$ Invasive Ductal, No pCR in the Breast & Axillary pCR & 0.26 & 0.89 & 2.33 \\
\hline 5 & $\mathrm{cN}=\mathrm{N} 0$, Surgery = Mastectomy, Regimen $=$ Chemotherapy, No pCR in the Breast & Axillary pCR & 0.25 & 0.90 & 2.34 \\
\hline 6 & $\mathrm{cN}=$ N0, Histology = Invasive Ductal, Regimen = Chemotherapy, No pCR in the Breast & Axillary pCR & 0.25 & 0.90 & 2.34 \\
\hline 7 & $\mathrm{cN}=\mathrm{N} 0$, Histology = Invasive Ductal, Surgery = Mastectomy, No pCR in the Breast & Axillary pCR & 0.25 & 0.90 & 2.33 \\
\hline 8 & $\mathrm{cN}=\mathrm{NO}$, Histology = Invasive Ductal, Surgery = Mastectomy, Regimen = Chemotherapy, No pCR in the Breast & Axillary pCR & 0.25 & 0.90 & 2.34 \\
\hline 9 & $\mathrm{cN}=\mathrm{N} 0, \mathrm{CT}$ Course $\leq 5$, No $\mathrm{pCR}$ in the Breast & Axillary pCR & 0.24 & 0.89 & 2.31 \\
\hline 10 & $\mathrm{cN}=\mathrm{NO}, \mathrm{CT}$ Course $\leq 5$, Regimen $=$ Chemotherapy, No pCR in the Breast & Axillary pCR & 0.24 & 0.90 & 2.33 \\
\hline
\end{tabular}

LHS, left-hand-side; RHS, right-hand-side; pCR, pathologic complete response; CT, chemotherapy.

\begin{tabular}{|c|c|c|c|c|c|}
\hline Rule ID & Antecedent (LHS) & Consequent (RHS) & Support & Confidence & Lift \\
\hline 1 & $\mathrm{PR}=$ Positive, Ki67 = Low Expression, Axillary pCR & No $\mathrm{pCR}$ in the Breast & 0.05 & 1.00 & 1.13 \\
\hline 2 & PR $=$ Positive, Ki67 = Low Expression, Regimen = Chemotherapy, Axillary pCR & No $\mathrm{pCR}$ in the Breast & 0.05 & 1.00 & 1.13 \\
\hline 3 & Histology = Invasive Ductal, $\mathrm{PR}=$ Positive, Ki67 = Low Expression, Axillary pCR & No $\mathrm{pCR}$ in the Breast & 0.05 & 1.00 & 1.13 \\
\hline 4 & $\mathrm{cT}=\mathrm{T} 2, \mathrm{ER}=$ Positive, $\mathrm{PR}=$ Positive, HER2 = Negative, Axillary $\mathrm{pCR}$ & No $\mathrm{pCR}$ in the Breast & 0.06 & 0.97 & 1.10 \\
\hline 5 & $\mathrm{cT}=\mathrm{T} 2, \mathrm{ER}=$ Positive, $\mathrm{PR}=$ Positive, HER2 = Negative, Regimen = Chemotherapy, Axillary pCR & No $\mathrm{pCR}$ in the Breast & 0.06 & 0.97 & 1.10 \\
\hline 6 & $\mathrm{cT}=\mathrm{T} 2, \mathrm{ER}=$ Positive, $\mathrm{PR}=$ Positive, HER2 $=$ Negative, Surgery = Mastectomy, Axillary pCR & No $\mathrm{pCR}$ in the Breast & 0.06 & 0.97 & 1.10 \\
\hline 7 & $\mathrm{cT}=\mathrm{T} 2, \mathrm{ER}=$ Positive, $\mathrm{PR}=$ Positive, $\mathrm{HER} 2=$ Negative, Surgery $=$ Mastectomy, Regimen $=$ Chemotherapy, Axillary pCR & No $\mathrm{pCR}$ in the Breast & 0.06 & 0.97 & 1.10 \\
\hline 8 & $\mathrm{cT}=\mathrm{T} 2$, Histology $=$ Invasive Ductal, $\mathrm{ER}=$ Positive, $\mathrm{PR}=$ Positive, HER2 $=$ Negative, Axillary pCR & No $\mathrm{pCR}$ in the Breast & 0.06 & 0.97 & 1.10 \\
\hline 9 & $\mathrm{cT}=\mathrm{T} 2$, Histology $=$ Invasive Ductal, ER $=$ Positive, $\mathrm{PR}=$ Positive, HER2 = Negative, Regimen = Chemotherapy, Axillary pCR & No $\mathrm{pCR}$ in the Breast & 0.06 & 0.97 & 1.10 \\
\hline 10 & $\mathrm{cT}=\mathrm{T} 2$, Histology $=$ Invasive Ductal, $\mathrm{ER}=$ Positive, $\mathrm{PR}=$ Positive, $\mathrm{HER} 2=$ Negative, Surgery $=$ Mastectomy, Axillary pCR & No $p C R$ in the Breast & 0.06 & 0.97 & 1.10 \\
\hline
\end{tabular}

LHS, left-hand-side; RHS, right-hand-side; PR, progesterone receptor; pCR, pathologic complete response; ER, estrogen receptor; HER2, human epidermal growth factor receptor 2.

\begin{tabular}{|c|c|c|c|c|c|}
\hline Rule ID & Antecedent (LHS) & Consequent (RHS) & Support & Confidence & Lift \\
\hline 1 & $\mathrm{PR}=$ Positive, Axillary $\mathrm{pCR}$ & No $p C R$ in the Breast & 0.14 & 0.92 & 1.04 \\
\hline 2 & $\mathrm{PR}=$ Positive, Regimen $=$ Chemotherapy, Axillary $\mathrm{pCR}$ & No $p C R$ in the Breast & 0.14 & 0.92 & 1.04 \\
\hline 3 & PR $=$ Positive, Surgery $=$ Mastectomy, Axillary pCR & No $p C R$ in the Breast & 0.14 & 0.92 & 1.04 \\
\hline 4 & Histology = Invasive Ductal, $\mathrm{PR}=$ Positive, Axillary pCR & No $p C R$ in the Breast & 0.14 & 0.92 & 1.04 \\
\hline 5 & $\mathrm{PR}=$ Positive, Surgery $=$ Mastectomy, Regimen $=$ Chemotherapy, Axillary $\mathrm{pCR}$ & No $p C R$ in the Breast & 0.14 & 0.92 & 1.04 \\
\hline 6 & Histology = Invasive Ductal, PR = Positive, Regimen = Chemotherapy, Axillary pCR & No $p C R$ in the Breast & 0.14 & 0.92 & 1.04 \\
\hline 7 & Histology = Invasive Ductal, PR = Positive, Surgery = Mastectomy, Axillary pCR & No pCR in the Breast & 0.14 & 0.92 & 1.04 \\
\hline 8 & Histology = Invasive Ductal, PR = Positive, Surgery = Mastectomy, Regimen = Chemotherapy, Axillary pCR & No $p C R$ in the Breast & 0.13 & 0.92 & 1.04 \\
\hline 9 & ER $=$ Positive, $\mathrm{PR}=$ Positive, Axillary $\mathrm{pCR}$ & No $p C R$ in the Breast & 0.13 & 0.92 & 1.04 \\
\hline 10 & PR $=$ Positive,$C T$ Course $\leq 5$, Axillary pCR & No $p C R$ in the Breast & 0.13 & 0.92 & 1.04 \\
\hline
\end{tabular}

LHS, left-hand-side; RHS, right-hand-side; PR, progesterone receptor; PCR, pathologic complete response; ER, estrogen receptor; CT, chemotherapy. 